\title{
Knowledge Level about Mother to Child Transmission of HIV/AIDS among Medical Student in Universitas Sumatera Utara
}

\author{
Albert Fiorentino Cuwardy ${ }^{* 1}$, Deri Edianto ${ }^{2}$ \\ ${ }^{1}$ Student, Faculty of Medicine, Universitas Sumatera Utara, Medan, North Sumatera, Indonesia \\ ${ }^{2}$ Department of Obstetrics and Gynecology, Faculty of Medicine, Universitas Sumatera Utara, Medan, \\ North Sumatera, Indonesia
}

\begin{abstract}
Background: HIV/AIDS is one of the diseases that has been a global problem for a long time. In 2018, there were 37.9 million people worldwide infected with HIV and 1.7 million were children. Knowledge of the prevention of HIV transmission from mother-to-baby is very important as one of the prevention options. The aim of research knowing the level of knowledge of students of the Faculty of Medicine, Universitas Sumatra Utara in 2017 against HIV transmission from mother to child. Method: Research method conducted using online survey method with cross sectional design. The samples used are all students based on total sampling. The study used univariate analysis to see descriptive images with primary data sourced from online questionnaires.

Result: The level of knowledge of students of the Faculty of Medicine, University of North Sumatra in 2017 in the category of both 128 people (63.7\%), enough 67 people $(33.3 \%)$, and less 6 people (3\%).

Conclusion: Students of the Faculty of Medicine, University of North Sumatra in 2017 have good knowledge about HIV transmission from mother to child.
\end{abstract}

Keywords: AIDS, HIV, Knowledge, Mother to Child, Transmission

\footnotetext{
*Corresponding author at: Student, Faculty of Medicine, Universitas Sumatera Utara, Medan, North Sumatera, Indonesia

E-mail address: cuwardy@gmail.com
} 
ABSTRAK

Latar Belakang: HIV/AIDS adalah salah satu penyakit yang telah menjadi masalah global sejak lama. Pada 2018, ada 37,9 juta orang di seluruh dunia yang terinfeksi HIV dan 1,7 juta adalah anak-anak. Pengetahuan tentang pencegahan penularan HIV dari ibu ke bayi sangat penting sebagai salah satu pilihan pencegahan. Tujuan penelitian untuk mengetahui tingkat pengetahuan mahasiswa Fakultas Kedokteran Universitas Sumatra Utara tahun 2017 terhadap penularan HIV dari ibu ke anak.

Metode: Penelitian dilakukan menggunakan metode survei online dengan desain potong lintang cross. Sampel yang digunakan adalah semua siswa berdasarkan total pengambilan sampel. Studi ini menggunakan analisis univariat untuk melihat gambar deskriptif dengan data utama yang bersumber dari kuesioner online.

Hasil: Tingkat pengetahuan mahasiswa Fakultas Kedokteran Universitas Sumatera Utara tahun 2017 kategori keduanya 128 orang (63,7\%), cukup 67 orang (33,3\%), dan kurang 6 orang (3\%).

Kesimpulan: Mahasiswa Fakultas Kedokteran Universitas Sumatera Utara tahun 2017 ini memiliki pengetahuan yang baik tentang penularan HIV dari ibu ke anak.

Kata Kunci: AIDS, HIV, Pengetahuan, Penularan dari Ibu ke Anak, Received 6 April 2021 | Revised 15 May 2021 | Accepted 31 May 2021

\section{Introduction}

At present, HIV infection continues to be a major problem in countries in the world, including Indonesia. In 2018, 37.9 million people were living with HIV with 36.2 million being adults and 1.7 million being children $<15$ years of age. There are 5,000 new HIV infections occurring every day with 4,400 infections being above> 15 years of age consisting of $47 \%$ women, $32 \%$ young women (15-24 years) and 20\% young women (15-24 years), and 500 infections among children under $<15$ years[1].

Knowledge of HIV and the mode of transmission significantly reduces the incidence of HIV infection. For this reason, one of the prevention at a young age is to increase the level of knowledge and education. One of the aspects contained in HIV / AIDS prevention is knowledge about the prevention of mother-to-child transmission of HIV / AIDS. Knowledge of the prevention of mother-to-child transmission of HIV is essential for using available prevention options. Women who have adequate knowledge about HIV prevention can protect themselves, their husbands, and their children from HIV infection and are more likely to undergo HIV testing than women who do not have adequate knowledge about HIV [2]. Lack of awareness and knowledge about MTCT causes more than $90 \%$ of new HIV infections among children [3]. About $90 \%$ of HIV infections in children are acquired through vertical transmission, transmission from 
pregnant women to their babies (MTCT) [4] [5]. HIV transmission from an HIV-positive mother from mother to child can occur during pregnancy, childbirth, and breastfeeding. If no intervention is carried out, transmission ranges are from $15 \%$ to $45 \%[6]$.

This research was conducted to determine the level of knowledge of students class of 2017 regarding the transmission of HIV / AIDS from mother to child because they will soon undergo clinical education at the hospital and will face HIV / AIDS sufferers directly. Through this study, researchers wanted to know the extent to which respondents could recall the material about HIV / AIDS that had been given in lectures some time ago during pre-clinical education.

\section{Method}

This research was conducted with an online survey method with a cross-sectional survey design with a sampling technique that is total sampling. The population in this study were all students of the Faculty of Medicine, Universitas Sumatera Utara class of 2017 count as 255 people with the number of respondents who were willing to fill out the questionnaire and meet the inclusion and exclusion criteria was 201 people. The inclusion and exclusion criteria were set by the author.

Inclusion Criteria Student of the Faculty of Medicine, Class of 2017. Understand how to fill out google forms and willing to fill out an online questionnaire. Exclusion Criteria: the questionnaire is filled in incompletely. The questionnaire presented to respondents is in the form of an electronic questionnaire which is a google form application that can be accessed online via the internet. The collected data is then processed and analyzed with the help of SPSS (Statistical Package for the Social Science) software. Which aims to explain or describe the characteristics of each research variable.

\section{Result}

The characteristics of respondents shows in table.

Table 1 Gender Distribution From Respondents

\begin{tabular}{ccc}
\hline Gender & Frequency $(\mathrm{N})$ & Percentage $(\%)$ \\
\hline Male & 72 & 36 \\
Female & 129 & 64 \\
\hline
\end{tabular}

Based on table 1 above, it can be seen that from the total number of respondents 201 people have met the inclusion and exclusion criteria, with the female gender count as 129 people (64\%) compared to the male gender with 72 people $(36 \%)$. 
Table 2 Age Distribution From Respondents

\begin{tabular}{ccc}
\hline Age (in the year) & Frequency $(\mathrm{N})$ & Percentage $(\%)$ \\
\hline 19 & 4 & 2,0 \\
20 & 52 & 25,9 \\
21 & 119 & 59,2 \\
22 & 19 & 9,5 \\
23 & 4 & 2,0 \\
24 & 1 & 0,5 \\
25 & 2 & 1,0 \\
Total & 201 & 100 \\
\hline
\end{tabular}

Based on table 2 above, it can be seen that the most respondents were 21 years old, count as 119 people (59.2\%), followed by 52 people aged 20 years (25.9\%), 22 years old count as 19 people (9.5\%), and age 19 and also 23 years respectively count as 4 people (2\%), age 25 years with 2 people $(1 \%)$, and the least in the age group of 24 years is 1 people $(0.5 \%)$.

Table 3 Respondents Knowledge Level

\begin{tabular}{ccc}
\hline Level of Knowledge & Frequency (N) & Percentage (\%) \\
\hline Good & 198 & 98,5 \\
Average & 3 & 1,5 \\
Total & 201 & 100 \\
\hline
\end{tabular}

Based on table 3 above, from a total of 201 respondents, 128 respondents $(63.7 \%)$ were in the good knowledge level group, then in the moderate knowledge group there were 67 people (33.3\%), and in the less knowledge were 6 people (3\%) 
Table 4 Variable of Knowledge in Questionnare

\begin{tabular}{ccccc} 
Variable & Good & Average & Poor & Total (\%) \\
\cline { 2 - 5 } Introduction & $198(98,5 \%)$ & $3(1,5 \%)$ & - & $201(100 \%)$ \\
Transmission way & $186(92,5 \%)$ & $13(6,5 \%)$ & $2(1 \%)$ & $201(100 \%)$ \\
Risk Factor & $75(37,3 \%)$ & $120(39,7 \%)$ & $6(3 \%)$ & $201(100 \%)$ \\
$\begin{array}{c}\text { Management of } \\
\text { Pregnant Women }\end{array}$ & $127(63,1 \%)$ & $49(24,4 \%)$ & $25(12,5 \%)$ & $201(100 \%)$ \\
$\begin{array}{c}\text { Management of Child } \\
\text { Prevention of } \\
\text { Transmission }\end{array}$ & $60(29,8 \%)$ & - & $141(70,2 \%)$ & $201(100 \%)$ \\
\hline
\end{tabular}

Based on table 4 above, in the question variable about HIV / AIDS to children, it can be seen that the majority of students have a fairly good knowledge of introduction, transmission methods, management of pregnant women and prevention of transmission. However, on the risk factors, it was found that some of the students knowledge was still in the moderate category and poor in the management of children infected with HIV/AIDS.

Table 5 Respondents Frequency Distribution Based on Information Sources.

\begin{tabular}{ccc}
\hline Source & Frequency $(\mathbf{N})$ & Percentage \% \\
\hline Parents / Friends / Relatives & 9 & $4,5 \%$ \\
Social Media & 0 & $0 \%$ \\
Printed Media & 67 & $33,33 \%$ \\
Radio / Television & 9 & $4,5 \%$ \\
Health Promotion & 2 & $1,0 \%$ \\
Health Workers & 40 & $19,9 \%$ \\
Expert Team Visit & 32 & $15,9 \%$ \\
Other & 6 & $3,0 \%$ \\
Total & 36 & $17,9 \%$ \\
\hline
\end{tabular}

Based on table 5 above, respondents can select and answer one main source of HIV / AIDS knowledge. Internet / social media became the most dominant source where 67 people made it a source of knowledge (33.3\%), followed by health promotion by 40 people (19.9\%), other sources besides those mentioned above were 36 people (17.9\%), 32 from health workers (15.9\%), 9 from 
parents/friends/relatives and print media each (4.5\%), 6 people (3\%) from visited by the expert team, 2 from radio/television people (1\%), and none of the community leaders / religious leaders.

\section{Discussion}

It can be seen that the majority of the respondents studied had a good level of knowledge about HIV / AIDS which consisted of knowledge of MTCT and PMTCT. In a study conducted by Sari [7] in 2011 on a group of medical students with a total sample of 150 people regarding knowledge of HIV / AIDS, it was found that 141 people had a good level of knowledge (94\%), and 9 people had a poor level of knowledge (6\%). While this is inversely proportional to a study conducted by Simatupang [8] in 2014 which contains knowledge of prevention of mother-to-child transmission of HIV / AIDS with a total sample of 91 people, the results obtained in this study were conducted in the 15-49 age group with a sample most were at the age of 25-29 years, respondents who had a good level of knowledge were only 10 people (11\%), a moderate level of knowledge was 25 people (27.5\%), and a lack of knowledge was 56 people (61.5\%).

Most of the student's knowledge level is at a good level and can relate to the sources of information received by students. The main sources listed are mostly from social media and health promotion. This can be seen from the research of Wahyuni et al in [9] it is known that in their research the most people getting information about HIV / AIDS in the student age group is through social media/internet. Apart from the lecture material, respondents also got information about HIV / AIDS from various other information. Also according to Sood et al [10] in 2007 social media and health promotion/campaigns can increase the level of knowledge about HIV / AIDS. These include being aware of HIV / AIDS infection, knowing how HIV is transmitted, being less misunderstood about how HIV is transmitted, and talking to others about HIV / AIDS than those who were not exposed to campaign messages. This is also supported by a meta-analysis study by LaCroix et al [11] in 1986-2013 which found that mass media campaigns can be useful in reducing the global HIV / AIDS discrepancy due to their reach and effectiveness.

\section{Conclusion}

From this study, it is known that the majority level of knowledge of students in the Faculty of Medicine, Universitas Sumatera Utara class of 2017 in a good category and the main source of information for students about HIV / AIDS was majority came from social media.

\section{REFERENCES}

[1] UNAIDS "Global HIV and AIDS statistics 2019 Fact sheet". Global HIV and AIDS stastistics, World AIDS day 2019 Fact Sheet. 2019. [Online]. pp. 1-6. Available: https://www.unaids.org/en/resources/fact-sheet [Accessed: 15 March 2020].

[2] Alemu, Y. M., Habtewold, T. D., Alemu, S. M. "Mother's knowledge on prevention of mother-to-child transmission of HIV, Ethiopia: A cross-sectional study". PLoS ONE, 
vol.13, no.9, pp.1-11. 2018.

[3] Luba, T. R., Feng, Z., Gebremedhin, S. A., Erena, A. N., Nasser, A. M., Bishwajit, G., Tang, S. "Knowledge about mother-to-child transmission of HIV, its prevention and associated factors among Ethiopian women". Journal of global health vol.7, no.2. 1017. 2017.

[4] Robert MBF, Joseph W, Nina F, Richard E “ Nelson Textbook of Pediatrics. 20 $0^{\text {th }}$ ed. Philadelphia: Elsevier. 2016.

[5] Yitayew, Y. A., Bekele, D. M., Demissie, B. W., Menji, Z. A "Mother to Child Transmission of HIV and Associated Factors Among HIV Exposed Infants at Public Health Facilities, Dessie Town, Ethiopia”. HIV/AIDS (Auckland, N.Z.), vol.11, pp. 343-50. 2019.

[6] Nguyen, R. N., Ton, Q. C., Tran, Q. H., \& Nguyen, T. "Mother-to-Child Transmission of HIV and Its Predictors Among HIV-Exposed Infants at an Outpatient Clinic for HIV/AIDS in Vietnam". HIV/AIDS (Auckland, N.Z.), vol.12, pp. 253-61. 2020.

[7] Sari, D. "Gambaran Pengetahuan, Sikap Dan Perilaku Mengenai HIV/AIDS Pada Mahasiswa Program Studi Pendidikan Dokter Universitas Tanjungpura". Skripsi Program Studi Pendidikan Dokter Fakultas Kedokteran Universitas Tanjungpura Pontianak. 2011.

[8] Simatupang, E. F. "Gambaran Perilaku Ibu Rumah Tangga terhadap Pencegahan Penularan HIV dari Ibu ke Janin di Kelurahan Tanjung Morawa Pekan Tahun 2013". Skripsi Fakultas Ilmu Kesehatan Masyarakat USU: Medan. 2013.

[9] Wahyuni, R., Susanti, D. "Gambaran Pengetahuan Mahasiswa Tentang HIV / AIDS Di Universitas Pasir Pengaraian Kabupaten Rokan Hulu". Jurnal Maternal dan Neonatal. Vol 2. pp 341-9. 2019.

[10] Sood, S., Shefner-Rogers, C. L., Sengupta, M. "The Impact of a Mass Media Campaign on HIV/AIDS Knowledge and Behavior Change in North India: Results from a Longitudinal Study". Asian Journal of Communication vol.16, no.3, pp 231-50. 2006.

[11] LaCroix, J. M. MS., Snyder, L. B., Huedo-Medina, T. B.; Johnson, B. T. "Effectiveness of Mass Media Interventions for HIV Prevention, 1986-2013: A Meta-analysis". JAIDS Journal of Acquired Immune Deficiency Syndromes: Vol.66, pp. S329-S340. 2014. 